\title{
Effect of Human Capital Development on Economic Growth of Ecowas Member States
}

\author{
Fadila Kabir Usman, Olure-Bank Adeyinka \\ Department of Economic, Faculty of Social Sciences, Nigeria Defence Academy, Kaduna, Nigeria \\ Email address: \\ sfadilakabir23@gmail.com (Fadila K. U.), adeyinka67@gmail.com (Olure-Bank A.) \\ To cite this article: \\ Fadila Kabir Usman, Olure-Bank Adeyinka. Effect of Human Capital Development on Economic Growth of Ecowas Member States. \\ Advances in Sciences and Humanities. Vol. 5, No. 1, 2019, pp. 27-42. doi: 10.11648/j.ash.20190501.14
}

Received: December 21, 2018; Accepted: January 10, 2019; Published: March 30, 2019

\begin{abstract}
This study examines the random effect of human capital development on economic growth of ECOWAS member states for the period of thirty seven years from 1980-2016, the measurement of random effect of human capital development on economic growth of ECOWAS member countries encompasses World Development Indicator and human capital index, four human capital variables are used, namely: expenditures on education (EED), expenditures on health (EHE), gross domestic product (GDP) and school enrollment (SCE), these variables were transformed to logarithm of base ten (10) to give more robust estimates, the economic growth was proxied by GDP, which is dependent variable, the empirical evidence is based on the Pedroni residual co-integration approach to test for the long-run relationship among the variables, the findings show that there is positive and significant relationship between GDP and government expenditure on education, expenditure on health and school enrollment in the ECOWAS counties, the study concludes that human capital development has an effect on economic growth in the ECOWAS region,the study is very relevant to the post-2015 Sustainable Development Goals agendas for two fundamental reasons: (a) Exclusive development is a critical policy syndrome in ECOWAS region where human capital development is a key to attain the SDGs extreme poverty target despite enjoying more than two decades of growth resurgence in some member states. (b) Growth in the region can primarily be driven by high human capital with the population of member countries expected to double in about 30 years, high investment on education and health for inclusive development is very welcome. This is essential because studies have shown that the increase in human capital development (resulting from increasing investment in education and health) would be enhances economic growth and development.
\end{abstract}

Keywords: Economic Growth, Economic Development, Education, Health, Human Capital, Government Spending, Institutions

\section{Background to the Study}

Human capital investment through education and health in developed and developing countries have attracted the attention of many economists, researchers and policy makers. The most important variables of human capital development are centered towards investment in the Educational and Health sectors. While education is a key input into the development of the research sector, that produces new knowledge and incentives which affects economic growth through making individual more efficient and productive. In addition it can lead to improved creativity, new technological inventions and innovation, Health on the other hand reflect state of complete well-being, be it physical or mental.

With, West African states tag as Least Developed
Countries (LDCs). ECOWAS accounts for $35 \%$ of the African LDC making West Africa the foremost LDC in Africa and the world. No Less than 11 of the 15 ECOWAS countries exhibit some of the lowest socio-economic development indicators, including the lowest Human Development Index ratings in the world.[1]

Despite all the polices put in place by the member states government, most countries in the region remain far low in Human Development Index rating, with about $80 \%$ of them falling below human development index counties and characterized by widespread poverty and inequality. The Human Development Index and ranking of ECOWAS member states according to human development reports 2016 are: Benin 0.485 ranked $167^{\text {th }}$, Burkina Faso 0.402 ranked 185th, Cape Verde 0.648 ranked 122th, Cote d'Ivoire 0.474 
ranked 171th , Gambia 0.452 ranked 173th, Ghana 0.579 ranked 139th, Guinea 0.414 ranked 183th , Guinea-Bissau 0.424 ranked 178th, Liberia 0.427 ranked 177th , Mali 0.442 ranked 175th, Niger 0.353 ranked 187th , Senegal 0.494 ranked 162th, Sierra Leone 0.420 ranked 179th, Togo 0.487 ranked $166^{\text {th }}$ and finally Nigeria as Africans leading oil producer and the most populous black nation in the world is scored as low as 0.531 and ranking of $152^{\text {nd }}$ out of the 188 counties in the African.[2]

However, most important factor in determining a country's productive capacity is the quality of its manpower and not its resource endowment, this is so because, a nation can have the natural resources and physical capital without the capacity to utilize them adequately due to lack of skills, research and development, training, innovation, technological knowhow. However, the impact of budgetary spending and policies of ECOWAS member countries on education and health needs to be examine.

With increasing low human development in ECOWAS member states, this study had in mind three rationale contemporary development studies, namely: (i) low investment on education and health, need to increase productivity so as to reduce poverty; (ii) growing exclusive development in the sub-region; and (iii) gaps in the literature. It is however important to note that only a healthy and educated population can be highly productive, as education and health are capable of driving productivity of a Nation. Low spending on education and health implies low quality education, more illiteracy rate, high motility rate and more diseases which will reflect on the nation's capacity to produce and thus low Gross Domestic Product (GDP). It is against this that the study intends to empirically analysis the exact effect of human capital development on the economy growth of the ECOWAS member countries. By filling the identified gap in the literature, the answers to the following research questions are sorted:

i. i. Does government expenditure on education influence economic growth of ECOWAS member countries?

ii. ii. To what extent has the level of school enrollment influence the economic growth of ECOWAS member countries?

iii. iii. To what extent has government expenditure on health influence economic growth of ECOWAS member states?

The above questions help to achieve broad objective of this study, to empirically examine the effect of human capital development on the economic growth of ECOWAS member countries and specific objective of the study are as follows. Assess the effect of government expenditure on education and health on the economic growth of ECOWAS member countries, and effect of school enrollment on economic growth of ECOWAS member countries. In other to examine the effect of human capital development on the economic growth of ECOWAS member countries, the following null hypotheses will be put forth for the purpose of this research:

i. $\mathrm{H}_{0}$ Government expenditure on education does not have significant impact on economic growth of ECOWAS member countries.

ii. $\mathrm{H}_{0}$ Level of school enrollment does not have significant effect on economic growth of ECOWAS member countries.

iii. $\mathrm{H}_{0}$ Government expenditure on health does not have significant impact on economic growth of ECOWAS member countries.

The policy interest of these is builds on the fact that the definition, measurement and conception of human capital development uses the outcome variable that is consistent with at least six of the seventeen Sustainable Development Goals (SDGs), namely: Goal 1. eradication of poverty in all its forms everywhere; Goal 2 eradication hunger, achieve food security and improved nutrition and promote sustainable agriculture; Goal 3 ensuring healthy lives and promote wellbeing for all ages; Goal 4 ensuring inclusive and equitable quality education and promote lifelong learning opportunities for all; Goal 8 promoting sustained, inclusive Goal 9 (sustainable economic growth, full and productive employment and decent work for all') and Goal 10 ('reduce inequality within and among countries') (SDGs).

The rest of the study is orgainsed as follows. Section 2 Discusses related literature. Section 3 Methodology, section 4 presents the empirical results. And section 5 conclude with implications and future research directions and recommendations.

\section{Literature Review}

\subsection{Introduction}

This chapter presents the conceptual review on economic growth, and human capital providing a theoretical base and empirical literature that presents evidence around the world and the study area; however the relationship between human capital development variables and economic growth are explained in the next sub-section as follows:

\subsection{Conceptual Review}

\subsubsection{Economic Growth}

Tadaro (2007) defined the term economic growth as a process by which the productive capacity of the economy is increased over time to bring about raising level of national output and income. Kuznets (1966) on the other hand views economic growth as a long term process wherein the substantial and sustained rise in real national income, total population and real per capita income takes place. Kindlerberge (1965) see economic growth to mean more output derived from greater efficiency. Friedman (1972) however views economic growth as an expansion of the system in one or more dimensions out a change in its structure. Thus economic growth is related to a quantitative sustained increase in the countries per capita output or income accompanied by expansion in its labour force, consumption, capital and volume of trade Jhingan (2013). From the above definitions its essential to understand that economic growth basically entails a long run process involving a period of time, increase in real per capital income 
level and volume of production linked with large increase in the productive ability of the economy, urbanization, equitable distribution of income and wealth among the population which result in reduction poverty and unemployment in a country.

\subsubsection{Human Capital}

Human capital has been recognized globally as one major factor that is responsible for the wealth of a Nations According to Smith (1776), he underlined the importance of "the acquired and useful abilities of all the inhabitants or members of the society" in he's works. Romele (2013) defined Human capital as the totality of knowledge and skills which have been accumulated during life, through education, training, and work experience and which influence labour productivity. Onakoya (2013) as cited in Adeyemi and Ogunsola (2016) described human capital as an important factor used in converting all resources to benefit mankind. In another dimension. Human capital is represented by the aggregation of investment in activities, such as education, health, on-the-job training and migration that enhance an individual's productivity in the labour market. [3] Frank \& Bemanke (2007) as cited in OECD (2009) defines that human capital is 'an amalgam of factors such as education, experience, training, intelligence, energy, work habits, trustworthiness, and initiative that affect the value of a worker's marginal product'. Therefore, human capital refers to the process of acquiring and increasing the number of people who have the skills, good health, education and experience that are critical for economic development.

\subsubsection{Human Capital Development}

Aluko (2015) defined Human capital development to mean enhances the skills, knowledge, productivity and inventiveness of people through a process of human capital formation broadly conceived. Thus, human capital development is a people centered strategy, and not goods centered or production centered strategy of development.

In the works of Torruam and Abur (2014) Human capital development can be seen to mean developing skills, knowledge, productivity and inventiveness of people through process of human capital formation. It is a people centered strategy of development which is recognized as an agent of national development in all countries of the world. Human capital formation refers to the process of acquiring and increasing the number of people who have the skills, good health, education and experience that are critical for economic development. [4] Human capital development refers to the process of acquiring and increasing the number of persons who have the skill, education, experience which are critical for the economic and political development of a country. Human capital development is thus associated with investment in man and his development as a creative and productive resource (Jhingan 2013).

Schultz (1960) in Jhingan (2013) categorized and developed human resources into six ways: (i) Heath facilities and services: - this involves all expenditure that affects the life expectancy, strength and stamina, and vigor and vitality of the people, (ii) On - the job training which includes old type apprenticeship organized by firms, (iii) Formally organized education at elementary, secondary school and higher level, (iv) Study programmes for adults that are not in agriculture, (v) It involves migration of individual and families to adjust changing job opportunity (factor mobility), (vi) Finally, transfer or importation of technical assistance, expertise and consultants.

The working definition for this research will be in line with Eggoh et al, (2015), Torruam and Abur (2014) and Romele (2013) that Human capital development is therefore the process of acquiring Knowledge, increasing good health, training to increase capability and creativity in other to develop the ability of the labour force which will reflect on the productive of an economy. Hence Human capital development is generally viewed from the expenditure on education, expenditure on health, and school enrollment. [5] (Hanif andArshed 2016)

\subsubsection{The Relationship Between Education, Health, and Economic Growth}

In the works of Akpolat (2014), a brief summary on education, health, and economic growth relationship was given: it was cited in some studies that associate education with economic growth which suggest four reasons for this relationship. (i) Education advances the efficiency of labor and thus production through scientific and technological developments. (ii) Education provides develop the potential skills of individuals. (iii) Education enhances the ability to adapt to emerging business opportunities. (iv) Educational institutions provide knowledge to be transferred to future generations by educating teaching staff. Moreover, the effect of education continues over generations owing to the fact that educated individuals cultivate healthier and more educated generations so they maintain the high human capital level of their society. Because the fertility rates of educated families are low, population growth will be balanced and savings per capita remain high. High level of saving rates positively contributes to economy. In addition to these, increase in educational level of society leads to an improvement on income distribution and prevents poverty because of its providing of advancement of individuals' high-earning capacity.

As for health and growth relationship, several reasons and channels are stated by economists on how health affects economic growth. First of all, healthier people reveal a more effective performance throughout their professional lives rather than people having low level of health. Furthermore, advances in health level of society increase the educational investments which increase the long-life expected returns of education. Besides these, improvements in health level of students bring about them having a better cognitive ability that helps to receive a better education. It was stated that taking malaria under control improves labor force and student efficiency. Improvements in both labor force and student efficiency positively affect economic growth, as it is known. It was noted that malnutrition in childhood is 
detected to relate with the low economic efficiency, the increase in life expectancy of adults leads to increase in their investments on their own children and so improves the human capital of next generations. However, decreasing mortality rates leads to increase in retirement age and so saving rates of society thus provide a high level of investments.

\subsubsection{Conventional Methods of Measuring Human Capital}

The conventional standard to measure human capital stock has been largely categorized into three parts: Output approach (School enrollment rates, scholastic attainments, adult literacy, and average years of schooling are the examples of output-based approach) Cost approach (costbased approach is based on calculating costs paid for obtaining knowledge) and Income-based approaches ( income-based approach is closely linked to each individual's benefits obtained by education and training investment).

\subsubsection{Output-Based Approach}

For the purpose of analyzing relationship between human capital and economic growth, some economists attempted to measure the stock of human capital utilizing 'school enrollment rates' as a proxy of human capital (Barro, 1991; Barro \& Lee, 1993). Throughout calculating the ratio between individuals of school age and students enrolling in the educational institutions, the economists show the stock of human capital that each country holds. However, the method includes a drawback that a student's effectiveness can be recognized after participating in production activities. In the perspective of educational attainment, Nehru, Swanson, \& Dubey (1993) attempted to measure relationship between human capital and students' 'accumulated years of schooling' in the employable age as educational attainment. Assuming that the stock of human capital is the sum of each individual's years of schooling; it is difficult to clearly demonstrate this relationship, because educational attainment is a part of regular (school) education. Actually, many of adults tend to participate in many formal education and training activities to improve their productivity.

Besides measuring the stock of human capital with school enrollment rates and educational attainment, Romer (1990) suggested the ratio between skilled-adults and total adults to measure the stock of human capital in the national economy. Furthermore, Organization for Economic Cooperation and Development (OECD) utilizes International Adult Literacy Survey (IALS), the ratio between literate adults and total adults, to measure the stock of human capital. Psacharopoulos \& Arriagada (1986) suggested the average years of schooling to measure the stock of human capital. They refer that the average years of schooling is meaningful to measure the stock of human capital as a proxy. This suggestion assumes that an individual's productivity is increased in proportion to his/her average years of schooling; they exemplify that someone's productivity with completing twelve years of schooling is twelve times compared to otherwise productivity with doing one years. As mentioned above, this method includes a drawback that an individual's years of schooling can be slightly related to his/her productivity.

\subsection{Theories of Human Capital Development}

\subsubsection{Modernization Theory of Human Capital}

The main focus of modernization theory is how education transforms an individual's value, belief and behavior. In fact, introduction to modernization institutions such as schools, factories, and mass media pound modern values and attitudes (like openness to new idea, independences from traditional authorities, willingness to plan and calculate further exigencies and growing sense of personal and social efficacy). According to those theorists, these normative and attitudinal changes continue throughout the life cycle, permanently altering the individual's relationship with the social structure. The level of individual modernity attained by the society increases according to the number of people exposed to modernization institutions.

Lucas (1988) built his model on Solow's model (1956) and assumed that investment in education leads to production of human capital which is critical in economic growth hence human capital accumulation as the engine of growth. He introduced a specification for human capital accumulation, which allows for endogenous growth. In the model, sustained per-capital growth is obtained through sustained human capital accumulation. That is, Lucas's model was to overcome diminishing returns to physical capital through the accumulation of human capital. Hence, physical capital can be accumulated without decreasing its marginal productivity since human capital is also growing at the same rate as physical capital. This endogenous growth model predicts that economic growth increases with effectiveness of investment in human capital.

\subsubsection{Theories of Economic Growth}

The theoretical underpinning of this research work is based on the inspiration drawn from the endogenous growth theory, which advocates the stimulation of economic growth and development through improvement in human capital within the model, using policies aim at increasing expenditure (both recurrent and capital) on education and health sectors. Furthermore, the models of economic growth effects of human capital are built upon the basis of Romer (1990) Mankiw-Romer-Weil model (1992) and Lucas (1988).

\section{Endogenous Growth Theories}

The model was developed my Arrow (1962), Romer (1990) and Lucas based on the limitation and deficiencies of Solow-Swan neoclassical model which has led to further investigation into the fundamental question of growth. It's a build on the exogenous theory which was based on technical change and exogenous population growth which does not matter what the government policy. The model explains the long growth rate of an economy on the basis of endogenous technical progress in the growth model resulting from the rate of investment, size of the stock of capital and human capital stock. 
The theory is based on the assumption that there are many firms in the market, knowledge / technological advance is non-rival good, there are increasing returns to scale to all factors together and content return to a single factor, technological advance come from creative new ideas, many individuals and firms have market power and earn profit from their discoveries

In particular, growth theorist has tried to indigenise the engine of growth, that is, to have the engine of growth determined within the model.

\subsection{Review of Empirical Literature on Human Capital and Economic Growth}

This subsection discusses reviews empirical literature on human capital and economic growth with respect to studies conducted around the world as well as Africa except for those in Economic community of West African states (ECOWAS).

Jameel and Naeem (2016) attemted to expose the relationship between human capital and economic growth in case of panel of eleven (11) countries for the period of 19922014, the results derived by applying panel econometrics tools show that there is a long term relationship between the real gross domestic product (GDP) and human capital in fixed effect OLS test.

In a similar study, Hanif and Arshed (2016) analyze the impact and contribution of primary, secondary and tertiary education and the importance of education in economic growth of SAARC region between 1960- 2013 using the ordinary least squares (OLS) and the fixed effect model (FEM). Findings showed that education has robust positive effect on economic growth and that the Government can achieve better results by investing heavily in educational sector.

Also, Mat, Mansur And Mahmud (2015) employed Ordinary least square (OLS) technique of analysis to study the effects of human capital investment on education, health And migration to economic development in Sabah (Malaysia) for the period of 1980-2010, Findings shows higher gross domestic product (GDP) per capita is Influenced by better literacy rate, longevity of life expectancy at birth and required Number of immigrants with a sustainable gross domestic savings and improvement in unemployment rate.

And in Africa, Mekdad, Dahmani and Louaj (2014) analyzed the relationship between public education expenditure and economic growth in Algeria using the Ordinary Least Squares (OLS) and Johansen Co-integration test and the Granger Causality Test technique for the period of 1974-2012 and The results support the main hypothesis of the study that Public spending on education affects positively economic growth in Algeria. Even though that the most important effect on economic growth is for education, the other three explanatory variables affect also, positively affect the economic growth even though, their effect is relatively less Important than the effect of education.

Again, Zivengwa, Hazvina, Ddedzu and Mavesere (2013) Investigates the causality between education and economic growth in Zimbabwe for the period of 1980-2008, results of the Granger causality and Vector Auto regression (VAR) Model confirmed that there is uni-directional causality between education and economic growth in the Zimbabwean economy running from education to economic growth as established by granger causality tests, variance decomposition and impulse response functions. The results also confirm a transmission mechanism that runs from education to economic growth via physical capital investment. This shows that a rise in human capital boosts the return on physical investment.

Again, Khembo and Tchereni (2013) analyzed the importance of human capital formation on economic development in South African development community (SADC). The study used panel data from the period of 1990 to 2005 collected from 13 ASDC countries. The results show that education is positively correlated with economic growth. Study recommends that any economy should give particular attention to the provision of health and education facilities for achieving the economic growth. Also, Sghari and Hammami (2013) analysis the relationship between health expenditure and GDP in developed countries from year 1975 to 2011 . The econometrics techniques like long run causality test granger causality and vector autoregressive are used to measure the relationship. They find that the long run relationship between increase in health care and economic growth is stable and also find that the relationship between health expenditure and economic growth is positive.

Reviews on human capital and economic growth with respect to studies conducted around the Economic community of West African states (ECOWAS). Obialor (2017) using Co-integration techniques and Vector Error Correction mechanism (ECM) to examine the effect of government human capital investment on the economic growth of three Sub-Sahara African (SSA) countries of Nigeria, South Africa and Ghana from 1980 to 2013, results indicate that two out of the three human capital proxy variables; Health,(GIH), and Education (GIE), show significant positive effect on growth only in Nigeria, while literacy ratio (LR)is insignificantly positive in all countries.

Also, Adeyemi and Ogunsola (2016) employed ARDL Cointegration analysis to explore the relationship between human capital indices (education and health) and economic growth in Nigeria for the period of 1980 -2013, Findings from the study revealed that there is positive long-run relationship among secondary school enrolment, public expenditure on education, life expectancy rate, gross capital formation and economic growth but it is statistically insignificant. The results also showed that there is negative long-run relationship among primary, tertiary school enrolment, public expenditure on health and economic growth.

To examine the growth effect of health in Ghana for the period 1982 to 2012, Boachie (2015) employed ARDL bounds test approach to co integration and found that economic growth is significantly driven by health, both in the short and long run. However, the favourable growth effect of health in the short run was found to be lower. Lawanson 
(2015) employs the dynamic Difference-Generalized Method of Moment (D-GMM) panel technique to empirically investigates the relevance of educational and health components of human capital to economic growth, using a panel data from sixteen West African countries over the period 1980 to 2013, the findings indicate that coefficients of both education and health have a positive statistically significant effects on GDP per capita thus affirms the strong relevance of human capital to economic growth of West Africa.

Owusu-Nantwi (2015) investigated the relationship between education expenditure and economic growth in Ghana. Vector error correction and cointegration analysis are employed to test for the causal relationship between the variables for the period 1970 to 2012. The empirical results show a positive and significant long-run relationship between Education expenditures and real GDP, gross capital formation as well labor force participation. The results indicate that education contributes meaningfully to the long-term growth of Ghana's economy. Also, in the short-run, Granger causality runs both directions between economic growth and education expenditures.

Bakare and Sanmi (2011) investigated the relationship between health care expenditures and economic growth in Nigeria, using the ordinary least square multiple regression analytical method. Their data analysis shows a significant and positive relationship between health care expenditures and economic growth. They noted that the key to good results lies not in ordinarily increasing particular budgetary allocation but rather in implementing a public finance system that, to the extent possible, links specific expenditure and revenue decisions and ensure the usage of the allocated funds as transparently as possible.

In a similar study, Olure-Bank, A.M \& Usman, Fadila Kabir (2018) investigates the impact of human capital (proxied by capital expenditures on education and health) on economic growth in Nigeria. In doing this, time series data from 1986 to 2016 were fitted into Cobb-Douglas production function using econometric techniques ordinary least square multiple regression analytical method (OLS). Empirical results affirmed that time series properties has significant and positive relationship between health expenditures and economic growth; while significant but negative relationship exist between education expenditures and economic growth. The study recommends that government should as a matter of policy invest heavily in social capital (education and health) to usher in the desired growth and development in Nigeria.

Concluding, studies have been conducted on human capital development across the globe just as Obialor (2017) but in he's work, he failed to include the important variable like the actual spending for education and health rather used only health and education and between the period of 1980-2013 which if the actual spending on these important variable were reflected it would have given a more robust result. However, Adeyemi and Ogunsola (2016) Boachie (2015); Olure-Bank, A.M \& Usman, Fadila Kabir (2018) study the important variables in human capital development analysis, but studying a single country out of fifteen (15th) member counties and a single county research can never depict the actual representation of all the ECOWAS member states since each country in the west African region has a different GDP as well as budgetary allocation on education and health. Although Lawanson (2015) employed a panel data approach in he's research to studying sixteen west African counties between 1980 to 2013 but unfortunately a country out of the state withdraw its membership out of the commission making west African commission a fifteen member countries at present therefore result obtained might not give the proper representation of the present ECOWAS states human capital development. Also, Owusu-Nantwi (2015) in he's analysis omitted expenditure on health in the research and also conducted a single country which will never give a good representation of the member counties. It is therefore against this background that the study intends to analysis the impact of human capita development on the economy of ECOWAS member countries.

\section{Methodology}

\subsection{Introduction}

This chapter describes the data used in this study and their sources. It also specify the models that was used in establishing the relationships among the variables of the study as well as the various estimation techniques. The panel regression model of the type developed by Pedroni (2000) was adopted in the study. The fundamental advantage of a panel data set over a cross section or time series is that it pools together both the cross sectional and time series elements thereby allowing the researcher great flexibility in modeling differences in behavior across individuals.

\subsection{Model Specification}

To examine the impact of human capital development on the economic growth of ECOWAS Member Countries the study will adopt a panel regression model specification. The model pools together both the cross sectional and time series elements in categories to be investigated. To achieve the broad and the specific objectives of the study the study will employ the fully modify ordinary least square (FMOLS) method of estimating and testing hypotheses for cointegrating vectors in dynamic time series panels. The model was originally designed in the work of Phillips and Hansen (1990) to provide optimal estimates for co-integrating regressions. Phillips and Hansen (1990) note that the FMOLS accounts for serial correlation effects and for the endogeneity in the regressors that result from the existence of cointegrating relationship. The data for this analysis was transformed into logarithm of base ten (10), before employing fixed exogenous FMOL. The advantage of this method, according to Pedroni (2000), is that it accommodates considerable heterogeneity across individual members of the panel. The general form of the model is given as: 


$$
\begin{gathered}
Y_{i t}=X_{i t} \beta+Z_{i t} \alpha+\mu_{i t} \\
X_{i t} \beta=C_{i}+\mu_{2 i t} \\
Y_{i}(G D P), X_{i}\left(\beta_{1} \text { GEE, } \beta_{2} \text { GEH, } \beta_{3} \text { SCE }\right)
\end{gathered}
$$

From (1) and (2) above, there are $K$ regressors in Xit, not including a constant term.

The heterogeneity or individual effect is $\mathrm{Z}_{\mathrm{it}} \alpha$ where $\mathrm{Zi}$ contains a constant term and a set of individual or group specific variables, which may be observed or unobserved, over time $t$. If $\mathrm{z} i$ is observed for all individuals, then the entire model can be treated as an ordinary linear model and fit by least squares. The complications arise when $c i$ is unobserved, which will be the case in most applications. From the models above, equation (2) is co-integrated with a co-integrating vector $\beta$ for each member of the panel if $Y_{i t}$ is integrated of order one.

\subsection{Sources of Data Collection}

The study used cross-sectional data which was collected from the World Development Indicator. The data for each member states cover a period of thirty seven (37) years from 1980 through 2016. The choice of 1980 to 2016 for the study was on the basis that most ECOWAS member states did not give attention to human capital as a strategy for development until in the early 80 's. Furthermore, the variables on which data was collected are school expenditures on education (EED), expenditures on health (EHE), gross domestic product (GDP) and enrollment (SCE). These variables were transformed to logarithm to base ten (10) to give more robust estimates. The economic growth will be proxied by GDP, which will be the dependent variable, while other variables (expenditure on education, expenditure on health, and school enrollment) serve as the independent variables.

\subsection{Estimation Techniques}

This section presents the estimation techniques. The estimation techniques cover panel unit root test, and panel co-integration. The next subsections present detail explanation of each of the estimation techniques.

\subsubsection{Panel Unit Root Test}

In most empirical studies, the most commonly used panel unit root test is that developed by Breitung (2000). This is on the basis that it has the highest power and smallest size distortions of any class of the so-called first generation panel unit root tests (Houskova and Wagner, 2006). The study will therefore adopt the panel unit root tests of Breitung (2000). The canonical forms of the models are given as:

$$
\begin{gathered}
y_{i t}=\eta_{i t}+\sum_{k=1}^{p+1} \beta_{i k} x_{i, t-k}+\varepsilon_{t} \\
H_{0}: \sum_{k=1}^{p+1} \beta_{i k}-1=0 \\
\sum_{k=1}^{p+1} \beta_{i k}-1<0 \text { for all i }
\end{gathered}
$$

Equation (4) is the difference stationarity equation, (5) is the null hypothesis to be tested against the alternative hypothesis in equation (5)

\subsubsection{Panel Co-Integration}

The panel co-integration model that was adopted in this study is that developed by Pedroni (2000). The test allows for two types of asymptotic tests which are "the withindimension approach and the between- dimension approach" that allow for heterogeneity among individual members of the panel, and heterogeneity in both the long-run cointegrating vectors and dynamics respectively. The model is stated as:

$$
Y_{i t}=\alpha_{i t}+\beta_{i t} t+\gamma_{i t} X_{i}+e_{i t}
$$

Where

$$
\begin{aligned}
& \mathrm{i}=1,2 \mathrm{~N} \\
& \mathrm{t}=1,2 \mathrm{~T}
\end{aligned}
$$

$\mathrm{N}=$ finite sample size

$\mathrm{T}=$ time period

$\mathrm{Y}_{\mathrm{it}}=$ vector matrix of dependent variables with $(\mathrm{N} * \mathrm{~T}) \times 1$ dimension for each member

$\mathrm{X}_{\mathrm{it}}=$ vector matrix of independent variables with $\left(\mathrm{N}^{*} \mathrm{~T}\right) \mathrm{x}$ $\mathrm{m}$ dimension for each member

$\alpha_{\text {it }}$ and $\beta_{\text {it }}=$ fixed effects for each country of the study

$\mathrm{t}=$ deterministic trend,

$\mathrm{e}_{\mathrm{it}}=$ is the stochastic error term.

other statistics associated with equation (9) In line with the Pedroni test are based on the within and between dimension approach, which are the panel v-statistics, panel $\rho$-statistic, panel PP-statistics, panel ADF-statistics, group q-statistic, group PP-statistic, and group ADF-statistic.the first four statistics pool autoregressive coefficients across various members for the unit root test to be carried out on the estimated residuals while the last three statistics are based on estimator simply average the individual estimated coefficient for each member. Thus the heterogeneous panel and the heterogeneous group mean panel co-integration test statistic(s) are specified as follows:

Panel v-statistic

$$
\mathrm{Z}_{\mathrm{v}}=\left(\sum_{\mathrm{i}=1}^{\mathrm{N}} \sum_{\mathrm{t}=1}^{\mathrm{T}} \hat{\mathrm{L}}_{11 \mathrm{i}}^{-2} \hat{\mathrm{e}}_{\mathrm{it}-1}^{2}\right)^{-1}
$$

Panel $\rho$-statisti

$$
Z_{\rho}=\left(\sum_{i=1}^{N} \sum_{t=1}^{T} \hat{L}_{11 i}^{-2} \hat{e}_{i t-1}^{2}\right)^{-1} \sum_{i=1}^{N} \sum_{t=1}^{T} \hat{L}_{11 i}^{-2}\left(\hat{e}_{i t-1} \Delta \hat{e}_{i t}-\hat{\lambda}_{i}\right)
$$

Panel PP statistic:

$$
Z_{t}=\left(\hat{\sigma}^{2} \sum_{i=1}^{N} \sum_{t=1}^{T} L_{11 i}^{-2} \hat{e}_{i t-1}^{2}\right)^{-\frac{1}{2}} \sum_{i=1}^{N} \sum_{t=1}^{T} L_{11 i}^{-2}\left(\hat{e}_{i t-1} \Delta \hat{e}_{i t}-\hat{\lambda}_{i}\right)
$$


Panel ADF

$$
Z_{t}^{*}=\left(\hat{s}^{* 2} \sum_{i=1}^{N} \sum_{t=1}^{T} L_{11 i}^{-2} \hat{e}_{i t-1}^{* 2}\right)^{-\frac{1}{2}} \sum_{i=1}^{N} \sum_{t=1}^{T} L_{11 i}^{-2} \hat{e}_{i t-1}^{*} \Delta \hat{e}_{i t}^{*}
$$

Group $\rho$-statistic:

$$
\tilde{Z}_{\rho}=\sum_{i=1}^{N}\left(\sum_{i=1}^{T} \hat{e}_{i t-1}^{2}\right)^{-1} \sum_{t=1}^{T}\left(\hat{e}_{i t-1} \Delta \hat{e}_{i t}-\hat{\lambda}_{i}\right)
$$

Group PP-statistic

$$
\tilde{Z}_{t}=\sum_{i=1}^{N}\left(\hat{\sigma}^{2} \sum_{i=1}^{T} \hat{e}_{i t-1}^{2}\right)^{-1 / 2} \sum_{t=1}^{T}\left(\hat{e}_{i t-1} \Delta \hat{e}_{i t}-\hat{\lambda}_{i}\right)
$$

Group ADF

$$
\tilde{Z}_{t}^{*}=\sum_{i=1}^{N}\left(\sum_{i=1}^{T} \hat{s}_{i}^{2} \hat{e}_{i t-1}^{* 2}\right)^{-1 / 2} \sum_{t=1}^{T}\left(\hat{e}_{i t-1}^{*} \Delta \hat{e}_{i t}^{*}\right)
$$

\subsection{A priori Expectation}

This refers to the sign and size of the parameters of economic relationship of the variables. All the independent variables (GEE, GEH and SCE) are expected to be positively related to GDP. Mathematically;

$$
\begin{aligned}
& \Delta \mathrm{GEE} / \Delta \mathrm{GDP}>0 ; \\
& \Delta \mathrm{GEH} / \Delta \mathrm{GDP}>0 ; \\
& \mathrm{SCE} / \Delta \mathrm{GDP}>0
\end{aligned}
$$

\section{Data Presentation and Analysis}

This section presents the results of the analysis carried out using E-views 8 statistical software to test the hypothesis earlier stated and ascertain the empirical working of our objectives. The section is divided into four sub-sections, namely, introduction, result of Breitung t-statistics for panel unit root, result of Pedroni residual cointegration test,
FMOLS, DOLS, pairwise granger causality test for panel data and finally discussion of findings.

\subsection{Data Analysis and Result Presentation}

In order to determine the impact of human capital development on the economic growth of ECOWAS member countries for the period of 1980 through 2016, this study conducted both descriptive statistics and inferential statistics and the results are presented as follows.

\subsubsection{Descriptive Statistics}

This section presents the descriptive statistics result on the study data. The section contains information on economic growth and human capital development for ECOWAS countries for the period of 1980 through 2016. More so, the information on human capital development is categorized into three major indicators, namely, government expenditure on education, government expenditure on education, and school enrollment within ECOWAS countries for the period under investigation. The descriptive statistics in the form of mean, minimum, maximum and standard deviation are contained in the tables below.

\begin{tabular}{|c|c|c|c|c|}
\hline Countries & Mean & Minimum & Maximum & S. Deviation \\
\hline BENIN & 2206581861.00 & 9103831278.00 & 4781037778.4054 & 2067449235.49199 \\
\hline BURKIN FASO & 2067688230.00 & 12008749185.00 & 5422844037.3243 & 3030186573.18463 \\
\hline CAPE VERDE & 193155976.60 & 16543518825.00 & 1297632193.6237 & 2608898665.56653 \\
\hline COTE D'IVOIRE & 1863071658.00 & 37045505519.00 & 21030109829.3947 & 5847164890.09658 \\
\hline GAMBIA & 331401394.80 & 16543518825.00 & 1060517894.4395 & 2589543097.35538 \\
\hline GHANA & 8344749210.00 & 48167546935.00 & 20700369332.0000 & 11707970076.21033 \\
\hline GUINEA & 2093182838.00 & 16543518825.00 & 4635673888.4211 & 2530234077.07950 \\
\hline GUINEA-BISSAU & 381901225.20 & 16543518825.00 & 1109689791.3026 & 2576387963.89303 \\
\hline LIBERIA & 240097055.80 & 16543518825.00 & 1788873785.6711 & 2576602376.22288 \\
\hline MALI & 2982230717.00 & 16543518825.00 & 6977148658.7368 & 3504387941.31433 \\
\hline NIGER & 2509557065.00 & 16543518825.00 & 4508529944.6053 & 2504728321.09891 \\
\hline NIGERIA & 16543518825.00 & 464282000000.00 & 210042145232.2369 & 122296137955.8862 \\
\hline SENEGAL & 4951868803.00 & 16851141949.00 & 9244798660.4474 & 3560023388.56252 \\
\hline SIERRA LEONE & 1287577162.00 & 16543518825.00 & 2387169517.3684 & 2459674243.52778 \\
\hline TOGO & 1639406827.00 & 16543518825.00 & 2885188240.9211 & 2379743997.49992 \\
\hline
\end{tabular}

\section{(i). Economic Growth for ECOWAS Countries}

Table 1 presents the economic growth for ECOWAS countries for the period under investigation. Gross Domestic Product for member countries serves as the indicator of economic growth

Table 1. Economic Growth of ECOWAS Countries (1980 - 2016).

Source: World Bank World Development Indicators, 2017.

Table 1 presents information on economic growth for ECOWAS countries for the period of 1980 through 2016. The information shows that Nigeria has on average high GDP for value followed by GIN. However, CPV has the least average GDP for the period. This shows that there are significant different GDP values for various countries. The minimum and maximum values and standard deviation value differ among member countries and period under study.

\section{(ii). Human Capital Development for ECOWAS Countries}

This sub - section presents information on human capital development proxied by government expenditure on education (Table 2), government expenditure on health (Table 3), and school enrollment (Table 4) for ECOWAS 
member countries for the period of 1980 through 2016 .

Table 2. Government Expenditure on Education in ECOWAS Countries (1980 - 2016).

\begin{tabular}{llll}
\hline Countries & Mean & Minimum & Maximum \\
\hline BENIN & 65.31 & 103.85 & 94.2753 \\
BURKIN FASO & 63.70 & 145.25 & 94.9093 \\
CAPE VERDE & 65.21 & 133.41 & 92.2363 \\
COTE D'IVOIRE & 17.33 & 102.63 & 84.8438 \\
GAMBIA & 70.70 & 109.35 & 91.2299 \\
GHANA & 70.72 & 115.51 & 88.3170 \\
GUINEA & 25.78 & 132.63 & 85.9243 \\
GUINEA-BISSAU & -23.09 & 148.66 & 83.8182 \\
LIBERIA & -34.95 & 161.45 & 84.1329 \\
MALI & -21.01 & 168.87 & 86.2804 \\
NIGER & 7.50 & 168.76 & 88.3460 \\
NIGERIA & 39.35 & 158.99 & 90.6335 \\
SENEGAL & 50.91 & 137.42 & 91.3705 \\
SIERRA LEONE & 43.42 & 114.02 & 88.33650 \\
TOGO & 33.63 & 107.23 & 10.14742 \\
\hline
\end{tabular}

Source: World Bank World Development Indicators, 2017.

Table 2 presents information on government expenditure on education for ECOWAS countries for the period of 1980 through 2016. The information shows that Ghana has the highest mean average spending on education even though it has the 2nd largest average mean GDP in the West African region economy and Liberia has the lowest expenditure within the specified period of review. However, the minimum and maximum values and standard deviation value differ among member countries.

Table 3. Government Expenditure on Health in ECOWAS Countries (1980 - 2016).

\begin{tabular}{llll}
\hline Countries & Mean & Minimum & Maximum \\
\hline BENIN & .62 & 36.34 & 11.4548 \\
BURKIN FASO & 1.37 & 10.57 & 3.7710 \\
CAPE VERDE & -20.73 & 98.60 & 35.1097 \\
COTE D'IVOIRE & -20.73 & 1534.67 & 46.4970 \\
GAMBIA & .41 & 39.37 & 8.3812 \\
GHANA & 1.62 & 138.97 & 53.1034 \\
GUINEA & .36 & 261.64 & 19.7694 \\
GUINEA-BISSAU & -60.51 & 403.09 & 12.0890 \\
LIBERIA & -37.52 & 544.54 & 28.1915 \\
MALI & 1.00 & 685.98 & 21.9602 \\
NIGER & .58 & 827.43 & 25.2452 \\
NIGERIA & .81 & 968.88 & 37.9778 \\
SENEGAL & .77 & 1110.32 & 38.78785 \\
SIERRA LEONE & -9.89 & 1251.77 & 38.6390 \\
TOGO & 1.38 & 1393.22 & 37.9495 \\
\hline
\end{tabular}

Source: World Bank World Development Indicators, 2017.

Table 3 presents information on government expenditure on health for ECOWAS countries for the period of 1980 through 2016. The information shows that just as spending on education, Ghana also tops the list followed by Togo with reference to highest average expenditure on health in the region, while Guinea-Bissau spend the least within the study period. More so, the minimum and maximum values and standard deviation value differ among member countries.

Table 4. School Enrollment in ECOWAS Countries (1980 - 2016).

\begin{tabular}{|c|c|c|c|c|}
\hline Countries & Mean & Minimum & Maximum & S. Deviation \\
\hline BENIN & 4.20 & 55.74 & 8.2081 & 8.61675 \\
\hline BURKIN FASO & 4.85 & 58.87 & 8.9983 & 8.87973 \\
\hline CAPE VERDE & 3.96 & 61.99 & 8.7376 & 9.50950 \\
\hline COTE D'IVOIRE & 4.47 & 99.51 & 12.4219 & 18.57435 \\
\hline GAMBIA & 3.11 & 65.12 & 8.9102 & 10.07875 \\
\hline GHANA & 3.00 & 68.25 & 8.6279 & 10.79624 \\
\hline GUINEA & 2.82 & 71.37 & 8.6605 & 11.41942 \\
\hline LIBERIA & 3.44 & 77.63 & 11.4380 & 11.92008 \\
\hline MALI & 4.99 & 80.75 & 10.5188 & 12.68095 \\
\hline NIGER & 4.95 & 83.88 & 10.7041 & 13.29891 \\
\hline
\end{tabular}




\begin{tabular}{lllll}
\hline Countries & Mean & Minimum & Maximum & S. Deviation \\
\hline NIGERIA & 2.43 & 87.01 & 9.2644 & 14.51233 \\
SENEGAL & 3.93 & 90.13 & 10.0259 & 14.91211 \\
SIERRA LEONE & 4.82 & 93.26 & 13.7690 & 14.62293 \\
TOGO & 3.88 & 96.39 & 10.4083 & 16.18364 \\
\hline
\end{tabular}

Source: World Bank World Development Indicators, 2017.

Table 4 presents information on school enrollment for ECOWAS countries for the period of 1980 through 2016. The information shows that Benin republic top highest with regards to number of its citizens enrolled in school and Nigeria despite having the largest economy in the region still top the list from behind. The minimum and maximum values and standard deviation value differ among member countries.

\subsubsection{Inferential Statistics}

This sub-section presents inferential statistics results. The results cover Breitung panel unit root test, Pedroni residual co-integration test Breitung panel unit root, panel pairwise Granger causality test, and long run covariance estimates.

Table 5. Breitung Panel Unit Root Test Results.

\begin{tabular}{llllll}
\hline \multirow{2}{*}{ Variable Names } & Level & \multicolumn{3}{l}{ First difference } \\
\cline { 2 - 5 } & T-statistics & Prob. & T-statistics & Prob. \\
\hline GDP & -12.7801 & 0.07801 & -11.5675 & 0.000 & I $(1)$ \\
GEE & -0.87124 & 0.1918 & 0.79238 & 0.0063 & I $(1)$ \\
GHE & -9.47479 & 0.2300 & -7.83223 & 0.000 & 0.000 \\
SER & -2.88547 & 0.1320 & -13.1637 & I $(1)$ & I (1) \\
\hline
\end{tabular}

Source: Author's Computation Using Eviews 8.

Table 6. Pedroni Residual Co-integration Test Results.

\begin{tabular}{lll}
\hline Test Statistics & T-values & Probability \\
\hline Panel v-Statistic & -3.744465 & 0.9999 \\
Panel rho-Statistic & -6.802628 & 0.0000 \\
Panel PP-Statistic & -15.88911 & 0.0000 \\
Panel ADF-Statistic & -15.05809 & 0.0000 \\
Group rho-Statistic & -7.067379 & 0.0000 \\
Group PP-Statistic & -18.17448 & 0.0000 \\
Group ADF-Statistic & -16.06134 & 0.0000 \\
\hline
\end{tabular}

Source: Author's Computation Using Eviews 8.

Table 1 above depicts the result of panel unit root test using Breitung t-statistics, null hypothesis for the test states that there is common unit root process in the data, decision for acceptance or rejection null hypothesis lies on the probability values, if the probability value of any test statistics is less than $5 \%$, we reject the null hypothesis and conclude that the series in question is stationary and vice versa. From the table, when economic growth (GDP) was subject to test of stationarity, we fail to reject the null at 5\% level, meaning that the level data of economic growth (GDP) is not stationary, when we take the first difference, it becomes stationary at $1 \%$, hence, we can easily conclude that economic growth (GDP) is integrated of order one. Level data on government expenditure on education has unit root with test statistics of -0.87124 , while its first difference yield a stationary series at $5 \%$ level of significant. Conclusion drawn from the series on government health expenditure, reveals that it is integrated of order one at $1 \%$ level. School enrolment is not stationary at level, but free from unit root after first difference. Conclusion drawn from the above table is that all the variables are integrated of order one; hence, we can test for co-integration as by Johansen (1999) and Pedroni (2000).

Table 2 above shows the result of panel co-integration test proposed by Pedroni (2000), he used seven test statistics to ascertain the existence or otherwise of co-integration among the variables in the long run. The null hypothesis for this state states that there is no co-integration, meaning that there is no long run relationship among the variables under investigation. By rule each of the test statistics should lead us to the rejection of null hypothesis. As shown above, with exception of panel v-statistics, all other statistics reject the null hypothesis of no co-integration, and those so at $1 \%$ level of significant. Out of seven test statistics, six tests namely; panel rho, panel pp, panel ADF, group rho, group pp and group ADF affirm the existence of co-integration because they reject the null hypothesis of no co-integration at $1 \%$ level of significant. We can easily conclude going by the majority that there exist long run relationship and causality among gross domestic product, government expenditure on education, government health expenditure and school enrolment. Theoretically, in the long run they move together.

Table 7. Panel Pairwise Granger Causality Test.

\begin{tabular}{llll}
\hline Null Hypothesis: & Obs & F-Statistic & Prob. \\
\hline GEE does not Granger Cause GDP & 525 & 0.42156 & 0.6562 \\
GDP does not Granger Cause GEE & & 1.24807 & 0.0128 \\
GHE does not Granger Cause GDP & 525 & 3.25561 & 0.0393 \\
GDP does not Granger Cause GHE & & 95.7806 & 4. E-36 \\
SER does not Granger Cause GDP & 525 & 1.85867 & 0.1569 \\
\hline
\end{tabular}




\begin{tabular}{lcll}
\hline Null Hypothesis: & Obs & F-Statistic & Prob. \\
\hline GDP does not Granger Cause SER & & 1.80206 & 0.0660 \\
GHE does not Granger Cause GEE & 525 & 0.83405 & 0.4349 \\
GEE does not Granger Cause GHE & & 1.22246 & 0.2953 \\
SER does not Granger Cause GEE & 525 & 1.68132 & 0.1871 \\
GEE does not Granger Cause SER & & 0.26649 & 0.0162 \\
SER does not Granger Cause GHE & 525 & 4.65022 & 0.0100 \\
GHE does not Granger Cause SER & & 36.0759 & 2. E-15 \\
\hline
\end{tabular}

Source: Author's Computation Using Eviews 8.

Table 3 above depicts the pairwise panel granger causality test, we reject the null if the probability value is less than $5 \%$ or $1 \%$. The null hypothesis are stated, we can compare the probability value to either accept or reject null hypothesis, from the table, there is unidirectional causality running from GDP to government expenditure on education and statistically significant at $5 \%$. As expected, government health expenditure granger cause GDP, this implies that human capital formation plays a significant impact in economic growth and development, the finding is statistically significant at $5 \%$ level, although it is unidirectional. We fail to reject the null that state that school enrolment does not granger ca use GDP, but reject the null that says GDP does not granger cause school enrolment although at $10 \%$ level. I found no causality whatsoever between government health expenditure and government expenditure on education this is because in both cases we fail to reject the null hypothesis. There is unidirectional causality running from government expenditure on education to school enrolment and statistically significant at $5 \%$. The null that school enrolment does not cause government health expenditure was rejected, while accept the alternative which state that school enrolment does granger cause government health expenditure not contrary i.e. unidirectional causality.

Table 8. Long Run Covariance Estimates (GDP as Dependent Variable).

\begin{tabular}{|c|c|c|c|c|c|c|}
\hline \multirow{2}{*}{ Variables } & \multicolumn{3}{|l|}{ FMOLS } & \multicolumn{3}{|l|}{ DOLS } \\
\hline & Coeff Coefficients & t-stati t-statistics & & Coefficients & t-statistics & \\
\hline GEE & 0.029053 & 0.151113 & GEE & 0.029053 & 0.151113 & GEE \\
\hline GHE & 0.723330 & 4.635803 & GHE & 0.723330 & 4.635803 & GHE \\
\hline SER & 0.159637 & 3.380610 & SER & 0.159637 & 3.380610 & SER \\
\hline
\end{tabular}

Source: Author's Computation Using Eviews 8.

Table 4 above depicts the long run covariance estimate of the model. Two separate models were estimated, fully modified ordinary least square (FMOLS) and dynamic ordinary least square (DOLS). As shown there is positive relationship between GDP and government expenditure on education, a unit raise in government expenditure on education will raise GDP by 0.029053 for FMOLS estimate, while raise GDP by 0.321267 in the case of DOLS estimate both are statistically significant at $5 \%$ level, . Government expenditure on health significantly raise output in ECOWAS countries, this is in consonance with already apriori expectation. This explains the high impact of the government expenditure on education in growing the GDP of the ECOWAS countries. Government health expenditure is positively and significant related to gross domestic product, as government expenditure on health increase by single unit growth of GDP will raise by 0.72330 and 0.047473 respectively in case of FMOLS and DMOLS. Government health expenditure constitute a significant important part of human capital formation, hence expenditure on health expenditure produced health individuals that work towards enhancing output in any economy. There is positive and significant relationship between school enrolment and GDP, and, by implication school enrolment enhances economic growth (GDP), this is in accordance with the a priori expectation. In the same vein there exist positive and significant relationship between economic growth (GDP) and school enrolment, the number of school intakes enhances capital formation most especially human capital formation, and this evidence is supported by theoretical literatures and significant at $5 \%$ level of significant. In all we can conclude that the proxy for human capital development positively impact on the economy of ECOWAS countries.

\subsection{Discussion of Findings}

This study used panel co-integration technique on secondary data source from World Bank World Development Indicator for the period of 1980 through 2016. The study estimates suggest that among other findings that human capital development (government expenditure on education, government expenditure on health, and school enrolment) significantly and positively determine economic growth of ECOWAS countries for the period under investigation. The finding revealed that government expenditure on education corroborates the findings of Obialor (2017) for Sub Saharan Africa especially Nigeria; and Lawanson (2015) for West African Countries but however contradicts the findings of Eggoh, Houeninvo and Sossou (2015) for African countries. This is to show that government expenditure on education plays significant role in economic growth all over the world as indicated by the findings by various scholars reviewed. Just like the government expenditure on education, this study established that government expenditure on health also plays a significant favourable impact on economic growth of ECOWAS countries. This finding also supports the 
findings of Olure-Bank, A.M \& Usman, Fadila Kabir (2018) for Nigeria; Kubowon, Mairara, Nyangwe, Muiruri and Cherotwo (2012) for Sub - Saharan Africa; Obialo (2017) and Lawanson (2015) for West Africa States; but however it contradicts the findings of Eggoh, Houeninvo and Sossou (2015); In line with Shaari (2014) study on Malaysia and Shahzad (2015) study on Pakistan, this study showed that school enrolment has significant positive impact on economic growth of ECOWAS countries.

\section{Summary, Conclusion and Recommendations}

\subsection{Summary}

This study assesses the effect of human capital development on economic growth of ECOWAS member countries using data spanning across all the 15 ECOWAS member countries over the period of 1980 to 2016. The data used were sourced from World Bank world development Indicators. The variables on which data were gathered include GDP, government expenditure on education, government expenditure on health and school enrollment indicators. The panel unit root test was conducted using Breitung t-statistics and findings shows that all the variables are integrated of order one. The panel co-integration test proposed by Pedroni (2000) was used to ascertain the existence or otherwise of co-integration among the variables in the long run and with exception of panel v-statistics out of seven test statistics (panel rho, panel pp, panel ADF, group rho, group pp and group ADF) confirms the existence of cointegration because they reject the null hypothesis of no cointegration at $1 \%$ level of significant thus affirms the existence long run relationship and causality among gross domestic product, government expenditure on education, government health expenditure and school enrolment. The pairwise panel granger causality test shows a unidirectional causality running from GDP to government expenditure on education and from government expenditure on health to GDP while school enrollment indicators does not granger causality GDP.

To test the long run covariance two separate models were estimated, fully modified ordinary least square (FMOLS) and dynamic ordinary least square (DOLS) and results shows that there is a positive and statistically significant relationship between GDP and government expenditure on education for both FMOLS and DOLS estimate at 5\% level. Government health expenditure is positively and significant related to gross domestic product using both test FMOLS and DMOLS. Thus, government health expenditure constitutes a significant important part of human capital formation. By implication health expenditure produced healthy individuals that work towards enhancing output in any economy. There is also positive and significant relationship between school enrolment and GDP at 5\% level of significant, indicating that school enrolment enhances economic growth (GDP). That is, the number of school intakes enhances capital formation most especially human capital formation. Hence, all the proxies for human capital development exert positively effect on the economy growth of ECOWAS countries supported by theoretical and empirical literatures, and therefore in line with a priori expectation.

\subsection{Conclusion}

Without a doubt, the empirical analysis conducted in the study show that the level of human capital development in ECOWAS member countries has significantly influenced the level of their economic growths. The human capital development has a positive relationship with the economic development of ECOWAS member states.

The human capital investment with emphasized on education, health and school enrollment may rapidly develop the economy of ECOWAS states. Human capital development on education may increase literacy rate regarding the additional schooling attained for knowledge, skills technological knowhow, the increase in human capital may increase job opportunities because people are willing to carry out business. Entrepreneurs are able to create job opportunities for the unemployed and avoid wastage of intellectual human capitals. However, human capital investment on health is refers to prevention of diseases by taking any medical care supplements and obtaining better health. Good nutrition absorbed by the body may increase the average labor productivity through the ability to work longer hours and rewarded additional income for health. Furthermore, the enrollment in school leads to more people acquiring knowledge. Therefore, human capital development is important for added values in the gross domestic product through education, health and school enrollment. Thus, the theory of the endogenous growth model supports the results of the study, that there is a positive relationship between human capital development and economic development of ECOWAS member counties.

\subsection{Ecommendations}

From the above, it is therefore recommended that the ECOWAS member government needs to set up appropriate policies that will modify the educational sector of the economy to improve its standard as well as making education affordable and accessible to all. To also adopt incentives that will improve teachers' quality, performances and availability of educational infrastructures to enable the countries human capital leads to possible economic growth and development.

The study also recommends that to achieving considerable and sustained economic growth, there is need to increase spending and investment in the health sectors of member countries of ECOWAS. In addition, more funds should be allocated to health sectors in line with other sectors.

However, investment in human capital should not be left to the government alone. The private sector of the economy should be actively involved in investment in human capital development, if the economy is to realize its objective of accelerated growth and development leading to collective 
self -sufficiency and raising the living standard among its member economies.

It is also suggests that no stone should be left unturned for universalization of school attainment, because increase in school enrollment at all levels of education will play significant role in the achievement of sustained economic growth in ECOWAS member countries. West Africa countries can only reposition herself as a potent force through the quality of its citizens from all the three levels of school systems as well as making its manpower relevant in the highly competitive and globalised economy through a structured and strategic planning of her educational institutions.

The study finally recommends that policy makers in the region should put in place policies that will help improve spending on human capital development and create awareness among people on the understanding of the importance of human capital development and its impact son economic growth.

Further research should study impact of others factors affecting human capital development apart from expenditure on education, expenditure on health and school enrollment with respect to economic growth in the ECOWAS region. However another relevant and important aspect is that of comparism between individual member countries and the region as a whole, as result of the two may vary.

\section{References}

[1] Adawo, M. A. (2011). Has education (human capital) contributed to the economic growth of Nigeria? Journal of Economics and International Finance, 3(1) 46-58.

[2] Adelakun, O. J. (2011). Human capital development and economic growth in Nigeria, European Journal of Business and Management, 3(9):29-37.

[3] Adeyemi, P. A., \& Ogunsola, A. J, (2016). The impact of human capital development on economic growth in Nigeria: ARDL approach, IOSR Journal of Humanities and Social Science (IOSR-JHSS), 21(3) 01-07.

[4] Afridi, A. H. (2016). Human capital and economic growth of Pakistan, Business \& Economic Review, 8 (1) 77-86.

[5] Afzal, M., Farooq, M. S., Ahmad, H. K., Begum, I., \& Quddus, M. A, (2010). Relationship between school education and economic growth in Pakistan: ARDL bounds testing approach to cointegration, Pakistan Economic and Social Review, 48(1) 39-60.

[6] Ajadi, O. T., \& Adebakin, A.B, (2014). Human capital development as correlate of economic growth in Nigeria, The African Symposium, 134 (14) 1-2.

[7] Akpolat, A. G. (2014). The long-term impact of human capital investment on GDP: a panel cointegrated regression analysis, Economics Research International, Article ID 646518, 10.

[8] Ali, S., Farooq, F., \& Chaudhry, I. S. (2012), Human capital formation and economic growth in Pakistan, Pakistan Journal of Social Sciences, 32(1): 229-240.
[9] Amassoma, D., \& Ikechukwu, .E. (2016). A Reappraisal of the Nexus between Investment in Human Capital Development and Economic Growth in Nigeria, Journal of Entrepreneurship, Business and Economics, 4(2):59-93.

[10] Arabi, K. A. M., \& Abdalla, S. Z. S, (2013). The impact of human capital on economic growth: empirical evidence from Sudan, Research in World Economy, 4(2).

[11] Bakare, A. S., \& Sanmi, E. D, (2011). The effect of health on economic growth: Theory and Evidence, NBER Working Paper Series, No 8587; available on http://www.nber.org/papers/w8587

[12] Barro, R. J., (1991). Economic growth in a cross-section of countries. Quarterly Journal of Economics, 106 407-443.

[13] Barro, R. J., \& Lee, J. W., (1993), International comparison of educational attainment, Journal of Monetary Economics, 32(3) 363- 394.

[14] Barro, R. J., (1990). Government spending in a simple model of endogenous growth, Journal of Political Economy, 98(5) $103-125$.

[15] Boachie, M. K., (2015). Effects of health on economic growth in Ghana: An application of ARDL bounds test to cointegration. MPRA Paper No. 67201, posted 21. October 2016 10:35 UTC.

[16] Breitung, J., (2000). The local power of some unit root test for Panel data in Baltagi.

[17] Dauda, R. O. S., (2010). Investment in education and economic growth in Nigeria: empirical evidence, International Research Journal of Finance and Economics, 24(55) 158-169.

[18] Edrees, A., (2016). Human capital, infrastructure and economic growth in Arab world: a panel granger causality analysis, Business and Economics Journal, 7(1):201.

[19] Eggoh, G., Houeninvo, H., \& Sossou, G. (2015). Education, health and economic growth in African countries, Journal of Economic Development, 40 (1),

[20] Ehimare, O. A., Ogaga-Oghene, J. O. O., Obarisiagbon, E. I., \& Okorie, U. E. (2014). The Nigerian government expenditure on human capital development: An efficiency analysis, European Journal of Business and Social Sciences, 3(7) 0113.

[21] Emmanuel, O. N. B., Wujung, V. A., \& Martin P., Emmanuel, S. M. P. (2014). Mechanisms of the influence of human capital on economic growth: a panel data analysis of the CEMAC region, Asian Economic and Financial Review, 4(5):625-640.

[22] Frank, R. H., \& Bernanke, B. S. (2007). Principles of Microeconomics (3rd ed.), New York: McGraw- Hill/Irwin.

[23] Friedman, J. (1972). Growth centres in regional economic development.

[24] Gebrehiwot, K. G. (2012). The impact of human capital development on economic growth in Ethiopia: Evidence from ARDL Approach to Co-Integration, International Journal of Humanities \& Social Science, 2 (4).

[25] Godstime, O. E., \& Uchechi, S. A. (2014). Human capital development and economic growth: The Nigeria experience, International Journal of Academic Research in Business and Social Sciences, 4 (4). 
[26] Hadir, A., \& Lahrech, A. (2015), Human capital development and economic growth in Morocco, International Journal of Education and Human Developments, 1 (1) 49.

[27] Hanif N., \& Arshed, N. (2016). Relationship between school education and economic growth: SAARC countries, International Journal of Economics and Financial. 6(1) 1 294-300.

[28] Havi, E. D. K., Enu, P., Attah-Obeng, F. O. P., \& Opoku, C. D. K. (2013). Macroeconomic determinants of economic growth in Ghana: Co integration approach, European Scientific Journal, 9 (19).

[29] Inuwa, N. (2012). Health expenditure and economic growth Nexus: An ARDL approach for the case of Nigeria. www.transcampus.org/journals, www.ajol.info/journals/jorind.

[30] Isola, W. A., \& Alani R. A. (2012). Human capital development and economic growth: empirical evidence from Nigeria. Asian Economic and Financial Review, 2(7) 813-82.7

[31] Jaiyeoba, S. V. (2015). Human capital investment and economic growth in Nigeria", Africa research review, 9(1):3046.

[32] Jameel, S. \& Naeem, M. Z. (2016). Impact of human capital on economic growth: A panel study, Bulletin of Business and Economics, 5(4):231-238.

[33] Javed, M., Abbas, S., Fatima, A., Azeem, M. M. \& Zafar, S. (2013). Impact of human capital development on economic growth of Pakistan: A public expenditure approach World Applied Sciences Journal 24 (3) 408-413.

[34] Jelilov, G., Aleshinloye. M. F \& Onder. S. (2016). Education as a key to economic growth and development in Nigeria; the international journal of social sciences and humanities invention, 3(02): 1862-1868.

[35] hingan, M. L. (2013). The economics of development planning, 38th edition. Delhi: Vrinda Publications (P) Ltd.

[36] Kakar, Z. K., Khilji, B. A., \& Jawad, M. (2011). Relationship between education and economic growth in Pakistan: A time series analysis. Journal of International Academic Research, $11(1): 27-32$.

[37] Khan, J., Khattak N. U. R. \& Khan, A. (2015). Human capitaleconomic growth nexus: A causality analysis for Pakistan, City University Research Journal 05 (2):07.

[38] Khan, J \& Khattak N. U. R (2013). The significance of research and development for economic growth: the case of Pakistan, City University Research Journal, 3 (2)

[39] Khattak, N. U. R \& Khan, J. (2012b). Does health accelerate economic growth in Pakistan? International Journal of Asian Social Science, 2 (4): 506-512.

[40] Khattak, N. U. R \& Khan, J. (2012a). The contribution of education to economic growth: evidence from Pakistan. International Journal of Business and Social Science, 3 (4):145-151.

[41] Khembo, F. \& Tchereni B.H.M. (2013). The impact of human capital on economic growth in the SADC Region, Developing Country Studies, Vol. 3, No.4: 144-152.

[42] Kindleberger, C.P. (1965). Economic Development.

[43] Kuznets, S. (1966.) Modern Economic Growth.
[44] Lawanson A. O. (2015). Economic growth experience of West African region: does human capital matter? International Journal of Business and Social Science 6(12).

[45] Lewis A 1956. Economic development with unlimited supplies of labour. Manchester School Studies, 22 139-191.

[46] Lucas S. R. (1988). The mechanics of economic developmente journal of monetary economics. 30-42.

[47] Lyakurwa, W. M. (2007). Human capital and technology for development: Lessons for Africa. $A F D B$.

[48] Mankiw N., Romer P. \& Weil D. (1992). A contribution to the empirics of economic growth. A quarterly journal of economics .407-437.

[49] Mehrara M. \& Musai M. (2013), The relationship between economic growth and human capital in developing countries, International Letters of Social and Humanistic Science, 5:5562.

[50] Mat N.A, Mansur .K \& Mahmud, R (2015). The relationship between human capital investment and economic development in Sabah. Malaysian, Journal of Business and Economics. $2(1): 83-107$.

[51] Mekdad, Y, Dahmani, A \& Louaj M. (2014), Public spending on education and economic growth in Algeria: causality test, International Journal of Business and Management. 2 (3): 55

[52] Mei-ling, S (2014) Empirical analysis on the relationship between human capital investment and economic growth in rural areas: Based on the data of Henan. Journal of Chemical and Pharmaceutical Research, 6(3) 378-382.

[53] Michael A. \& Oderinde O. (2012). Public education expenditure and defence spending in Nigeria: An empirical investigation. An implication of vector auto regression (VAR) models, powered by mooreadvice, 2012 .

[54] Muhammed A., Bilah M. \& Muhammed S. (2012). Impact of human capital on economic growth with emphasis on intermediary role of technology: Time series evidence from Pakistan. Africa Journal of Business Management, 6: 280-285.

[55] Mulligan, C., \& Sala-i-Martin, X. (1995). Measuring aggregate human capital. NBER Working Paper no. 5016. Combridge, MA: National Bureau of Economic Research.

[56] Ndambiri, H. K., Ritho C., Ng'ang'a .S. I., Kubowon, P. C., Mairura F.C., Nyangweso P.M., Muiruri E. M. \& Cherotwo F. H.(2012) Determinants of economic growth in sub-saharan Africa: A panel data approach, International Journal of Economics and Management Sciences, 2(2):18-24.

[57] Nehru, V., Swanson, E., \& Dubey, A. (1993). A new database on human capital stock sources, methodology, and result. Working Paper No. 1124, Washington DC: World Bank.

[58] Nelson, R, \& Pack H (1999). The Asian miracle and modern growth theory, Economic Journal, 109 (457):416.

[59] Nelson, R, \& Phelps, E. (1966). Investment in humans, technological diffusion, and economic growth" American Economic Review, 61: 69-75.

[60] Novignon, J., Nonvignon, J., \& Arthur, E. (2015). Health status and labour force participation in Sub-Saharan Africa: a dynamic panel data analysis. African Development Review, 27(1), 14-26. 
[61] Nurudeen, A. \& Usman, A. (2010). Government expenditure and economic growth in Nigeria, 1970-2008: A disaggregated analysis. Business and Economic Journal, 6(20):23-40.

[62] Obialor M. C (2017). The effect of government human capital investment on the economic growth of Sub-Sahara African (SSA) countries evidence from Nigeria, South Africa and Ghana (1980 to 2013). International Journal of Asian Social Science, 2017, 7(4): 328-339.

[63] Odit M. P, Dookhan M. K \& Fauzel M. S, (2010). The impact of education on economic growth: the case of Mauritius. International Business \& Economics Research Journal 9 (8):141-156.

[64] Oisaozoje I. A, \& Isaac O. M (2016). Impact of human capital development on economic growth in Nigeria. International Journal of Business and Management Invention, 5(3): 62-68.

[65] Oluwatobi, S. O, \& Ogunrinola, I. O. (2011) Government expenditure on human capital development: Implications for economic growth in Nigeria. Journal of Sustainable Development. 4(3).

[66] Omotayo O. A. (2015). Impact of human capital development on economic growth in Nigeria. International Journal of Recent Research in Commerce Economics and Management (IJRRCEM) 2(2):151-164

[67] Owusu-Nantwi, V. (2015). Education expenditures and economic growth: evidence from Ghana. Journal of Economics and Sustainable Development. 6(16): 69.

[68] Pedroni, .P (2000). Fully modified OLS for heterogeneous cointegrated panel, Advances in Econometrics, 15: 93-130.

[69] Phillips, P., \& Hansen, B. (1990). Statistical inference in instrumental variables regression with I (1) Processes. Review of Economic Studies, 57:99-125.

[70] Psacharopoulos, G., \& Arriagada, A. M. (1986). The educational attainment of the labor force: an international comparison. International Labor Review, CXXV: 32-52.

[71] Rastogi, P.N., (2002). Knowledge management and intellectual capital as a paradigm of value creation. Human systems Management, 21(4):229-240.

[72] Risikat O. S. D. (2010). Investment in education and economic growth in Nigeria: an empirical evidence, International Research Journal of Finance and Economics.

[73] Rodriguez, P. J., \& Loomis, R. S. (2007). A new view of institutions, human capital, and market standardization education, knowledge \& economy, 1(1): 93-105.

[74] Romele, L. (2013). Human capital development and economic growth in Latvia, European Scientific Journal, 9 (31).

[75] Romer, P. M, (1986). Increasing returns and long run growth", Journal of Political Economy, 94, 1002-37.

[76] Romer, P. M. (1990). Endogenous technological change. Journal of Political Economy, 98(5), 71-102.

[77] Rosen, H. S. (1999). Public Finance. New York: McGraw-Hill.

[78] Saad, W. \& Kalakech, K. (2009). The nature of government expenditure and its impact onSustainable economic growth" Middle Eastern Finance \& Economics, Issue 4 (2009), Euro Journals Publishing, Inc. 2009: 38-47.
[79] Samar B \& Waqas M (2014), Human capital formation and economic growth in Pakistan, World Applied Sciences Journal 32 (4): 635-641.

[80] Schultz T. P. (1992).The role of education and human capital on economic development. An empirical assessment center discussion paper, economic growth center, Yale University.

[81] Sesay .A \& Omotosho .M (2011) The politics of regional integration in West Africa, WACSERIES 2(2).

[82] Sghari, M. B. A., \& Hammami, S. (2013). Relationship between health expenditure and GDP in developed countries. IOSR Journal of Pharmacy, 3(4): 41-45.

[83] Shaari, M.S (2014) Education-led Economic Growth in Malaysia, Sop Transactions on Economic Research. 1(1)

[84] Shahzad, F. (2015). Role of human capital on economic growth: A case study of Pakistan International Journal of Accounting and Economics Studies, 3 (1) 20-24.

[85] Shahzad, F. (2015), Role of human capital on economic growth: A case study of Pakistan, International Journal of Accounting and Economics Studies, 3 (1), 20-24.

[86] Shah, S.W.A, Shahzad, S K, \& Haq, M.A (2015), Human capital and economic growth: evidence from selected asian countries, Journal of Resources Development and Management. An International 11(22).

[87] Theodore R. B, (2012) The role of education in economic development: Theory, History, and Current Returns.

[88] Todaro, M. P. \& Stephen, C. S. (1982). Economic for developing countries. Longman publishers. London.

[89] Todaro, P. (2007). Economic development: Pearson Education, 8th Edition, India.

[90] Torruam, J. T \& Abur, C. C. (2014) Public expenditure on human capital development as a strategy for economic growth in Nigeria: application of co integration and causality test analysis, International Journal of Research in Humanities and Social Studies, 1(2): 14-23.

[91] Umaru, A. (2011). Human capital: education and health in economic growth and development of the Nigerian. British journal of economics, Finance and Management Sciences, 2(1): 22-36.

[92] UN (1997), Glossary of environment statistics. Studies in methods, Series F, No. 67, United Nations, New York.

[93] UNDP (1996): Human development report New York Oxford University press.

[94] UNDP. (2011). Human development report: sustainability and equity: a better future for all. the united nations development programme, UN Plaza, New York, USA.

[95] UNESCO, 2005, World report: towards knowledge societies, UNESCO Publishing.

[96] UNESCO. (2010). UNESCO Institute for statistics data base, Available at www.uis.unesco.org (accessed on November (22).

[97] WDE. (2010). World data on education.7th Edition, UNESCO-IBE.

[98] World Health Organisation (1946). Publications on health. 
[99] World Bank (2017). World Development Indicator 2017 on CD-ROM World Bank Washington DC.

[100] Zivengwa, T, Hazvina. F, Ndedzu, \& Mavesere I, M (2013).
Investigating the causal relationship between education and economic growth in Zimbabwe, Asian Journal of Humanities and Social Studies. 1 (5): 399. 